\title{
Teachers' attitude towards translanguaging practice and its implication in Indonesian EFL classroom
}

\author{
Fransiskus Dinang Raja*, Suparno, and Ngadiso \\ English Education Department Teacher Training and Education Faculty, Universitas Sebelas Maret, \\ 36 Ir. Sutami Road, Surakarta City, Central Java, Indonesia
}

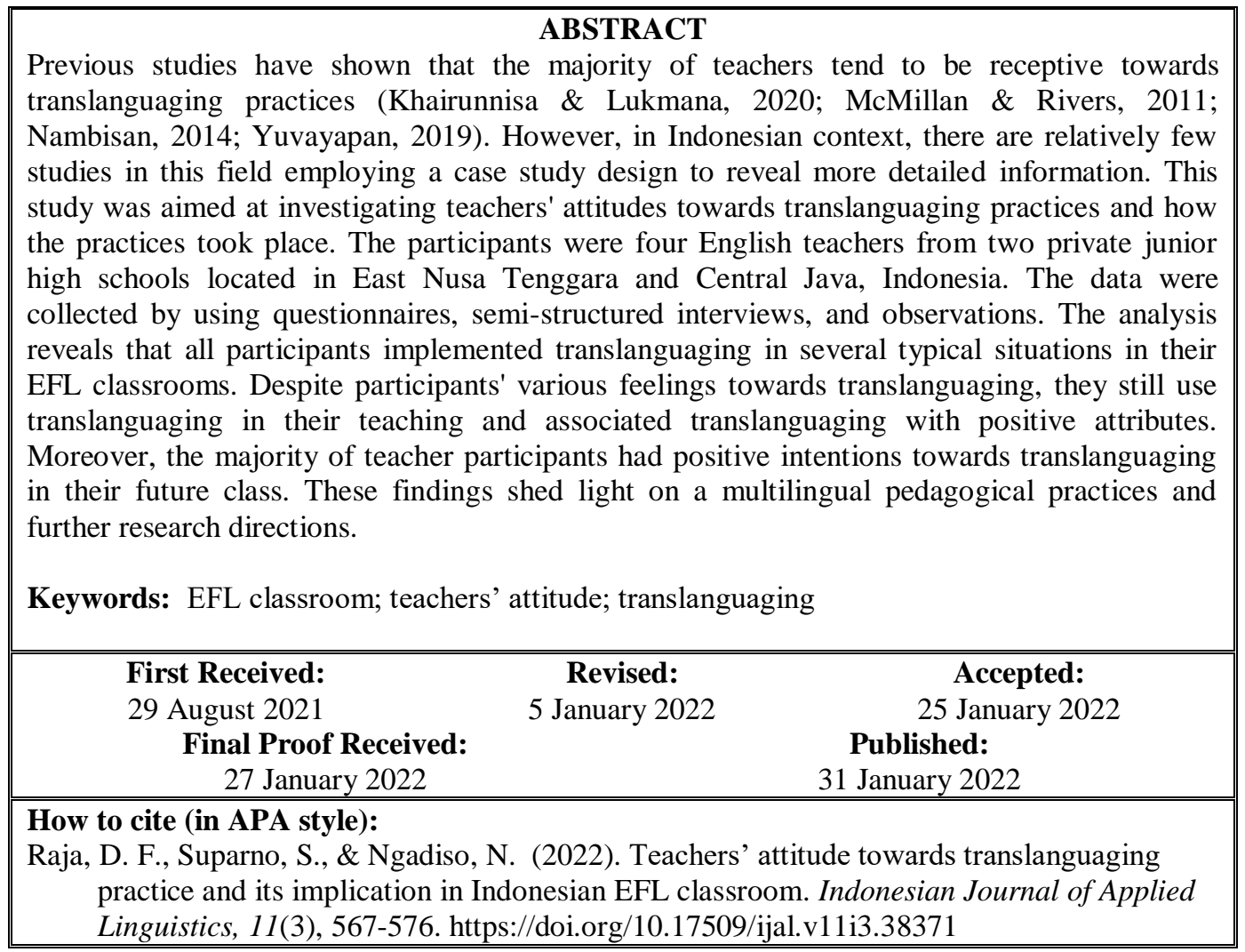

\section{INTRODUCTION}

The concept and strategy of translanguaging are increasingly developed in education to promote students' academic performance by using their alllinguistic resources. Students who are involved in translanguaging will experience a language practice in which two or more languages are used for pedagogical purposes. The students will gain more advantages as what are pointed out by Baker; First, it results in a deeper and fuller understanding of the learning material because the use of two languages demands a process that never happens in the monolingual system. Second, the language they have not yet mastered well will be strengthened. Third, parents who speak minority languages can help students' development in minority languages by communicating in that language at home. Fourth, it enables students who have better English proficiency to help those who do not (Baker, 2001).

Although it is thought that translanguaging is beneficial especially in the multilingual settings, translanguaging can be very challenging at the same time. Even Garcia and Wei who make efforts to develop this theory realize this issue. Most schools have never granted translanguaging space for their students through their official school language policy because of the complexities that may be faced by the teachers and students in the classroom. Many argue that only the "language" as defined in national school curricula and grammar books is important and needs to be used in schools while translanguaging seems to blur them all. Another tension in translanguaging implementation is the perspective of those who believe that accepting the

\footnotetext{
* Corresponding Author

Email: dinangraja90@student.uns.ac.id
} 
fluid language practices of bilinguals will weaken the non-dominant language (Wei \& García, 2017).

Encountering this situation, whether or not to translanguage in the classroom, further studies need to be conducted including the study of attitude towards translanguaging. Canagarajah asserts the importance of studying attitude towards translanguaging to understand the possibilities of pedagogical success (Canagarajah, 2011b). The study must involve the multilingual teachers and students who used to translanguage in their classroom (Wang, 2019). By studying attitude, we will know how those people evaluate translanguaging based on their real experiences. The most interesting participants in the study of attitude towards classroom translanguaging are teachers. As the policy-maker in the classroom context, teacher policy enactment plays a significant role in supporting or constraining the pedagogical goals (Zuniga et al., 2017) including the decision to embrace or not translanguaging strategies. The decision must be made based on particular considerations related to the teachers' beliefs of translanguaging benefits and challenges that can also be revealed in the study of attitude.

Since translanguaging was firstly introduced by Cen Williams as a pedagogical practice in Welsh/English classrooms, scholars have conducted many studies investigating teachers' attitudes towards the practice. Some studies revealed almost positive findings reflecting teachers receptive stance (McMillan \& Rivers, 2011; Nambisan, 2014; Yuvayapan, 2019). Those findings were also supported by the studies conducted in Indonesia. A descriptive quantitative study indicated that most Indonesian Elementary EFL teacher supported the incorporation of Indonesian language and local language in EFL classrooms especially for assisting the low English proficiency students (Khairunnisa \& Lukmana, 2020). During the teaching and learning process, most teachers opted for involving languages other than English to facilitate them achieving pedagogical purposes while not forgetting the students who encountered the difficulties in learning English.

In general, the present study extends what previous scholars have done by employing a case study design (Yin, 2018) and involving few numbers of participants. As this study includes the openended questionnaires and interviews, the participants enable to express what they truly feel and believe about using all linguistic repertoire in their multilingual classroom context. They have more space to elaborate their idea which may not only to support the translanguaging practice but also the challenges they experience during their teaching. Moreover, through the classroom observations, the actual practices of translanguaging in the participants' EFL class can also be captured more.
This study investigates three main points, namely, teachers' attitude towards teacher-directed and student-directed translanguaging (Cenoz, 2017; Jones, 2017; Lewis et al., 2012), and how translanguaging take place in the Indonesian EFL class. The main questions that guided this study include:

1. How is EFL teachers' attitude towards teacher-directed translanguaging in Indonesian EFL classrooms?

2. How is EFL teachers' attitude towards student-directed translanguaging in Indonesian EFL classrooms?

3. How is translanguaging practice carried out in the Indonesian EFL classrooms?

\section{METHOD \\ Respondents}

The participants were four grade VIII English teachers of two private Junior High Schools. Teachers 1 and 2 were from the school located in Central Java while Teachers 3 and 4 were from East Nusa Tenggara. They were purposely chosen based on particular consideration that was related to the aims of the present research. The criteria employed to select the participants were EFL teachers who had direct experiences through repeated exposure of translanguaging and were open to share their personal thoughts and experiences regarding translanguaging practices in their EFL class.

Participants' ages ranged from 26 to 46 years old. Three participants had teaching experiences under five years while one senior teacher had taught English for more than 5 years. All participants spoke at least 3 languages namely English, Indonesian and their own indigenous language with different proficiency. They rated themselves as highly proficient for English and Indonesian. For indigenous language, Teacher 4 reported that she was just able to have limited conversation on everyday topics while the other 3 teachers did not have too much communication problems using their indigenous languages.

\section{Instruments}

Data collection was obtained from three instruments: observation, questionnaires, and interviews. The observations were conducted four times, once for each participant's class. The questionnaires consisting of two main sections were employed with close-ended and open-ended questions. The first section was intended to reveal teachers' identity, language background, and language proficiency while the second section was mainly designed to investigate teachers' attitudes towards translanguaging practices. In this second section, open-ended questions were employed demanding the further explanation of participants' feelings, beliefs, and intentions towards translanguaging directed by 
both teachers and students. Lastly, the semistructured interviews involved four participants to reconfirm what they have said in the questionnaires and to dig out more detailed information.

\section{Procedures}

The participants were firstly asked to be observed once in their EFL class. During the observation, the researcher played as the passive observer who focused on observing, recording, and noticing the whole teaching and learning process especially at the moments where classroom language practices took place. After that, the teacher participants had to fill in the online questionnaires as described previously and were given the interviews. The researcher employed interview guidelines based on their filled questionnaires so that participants could voice their experiences unconstrained by any perspectives of the researcher or past research findings. The time and place of the interview were set based on the agreement of the researcher and participants. The result of the interview was recorded, transcribed, and analysed.

\section{Data Analysis}

The collected data from classroom observations, questionnaires and interviews were analysed and proceed with the following activities: (1) data condensation, (2) data display, and (3) conclusion drawing/verification (Miles et al., 2014). During the first activity, keywords and sentence analysis were utilized to categorize participants' attitudes as positive or negative based on their verbal expressions of feelings (affect), beliefs (cognition), and intentions (conation). A sentence or argument which was not marked as a positive or negative evaluative term was deemed as mixed. The results of the analysis were put into tables covering the data analysis of the questionnaires and interview transcriptions of the four teachers.

\section{FINDINGS AND DISCUSSION}

\section{Teachers' attitude towards Teacher-directed Translanguaging}

The following Table 1 illustrates the teachers' attitude towards teacher-directed translanguaging.

Table 1

Teachers' Attitude Towards Teacher-Directed Translanguaging

\begin{tabular}{llll}
\hline & Affect & Cognition & Conation \\
\hline T1 & Mixed & Positive & Positive \\
T2 & Positive & Positive & Positive \\
T3 & Negative & Positive & Positive \\
T4 & Negative & Positive & Mixed \\
\hline
\end{tabular}

Most teachers express the positive attitude towards teacher-directed translanguaging which is reflected through the eight positive comments that can be seen in the table. There are also two negative comments while two other comments are mixed.

\section{Affect}

Each participant feels different emotions towards teacher-directed translanguaging. Teacher 1 has a mixed feeling. Rather than mentioning certain emotions which can be categorized as pleasant or unpleasant, Teacher 1 reports that teacher's use of languages other than English namely Indonesian and Javanese as something normal.

"I feel it is normal considering students' grades. In grade VII, I used Indonesian and Javanese more often but in grade VIII or higher, it has been reduced gradually because the students have become familiar with English."

Unlike Teacher 1, Teacher 2 has a more positive feeling. She admits that she feels comfortable to use languages other than English in the class.

"I feel comfortable when I have to use Indonesian or Javanese. Most students in my class have never been taught English in Elementary School. Some of them go to English courses and usually they are better compared to their friends who don't. Even, when they are already in grade VIII now, I feel that I still have to use Indonesian and Javanese to make sure that all of them understand the materials."

For Teacher 2, incorporating Indonesian and Javanese in her EFL class copes with the diverse students' profile in term of their language background and English proficiency. Employing translanguaging can close the gap between the students' proficiency level caused by the national curriculum provision. In their foregoing formal education, students in Indonesia mostly do not have a chance to learn English (Faridatuunnisa, 2020; Zein, 2017) except some students who had an English private study out of school. Even though they are already in grade VIII, the gap between the students who have learned English in the Elementary school and those who do not still obvious. Thus, the teacher's use of Indonesian and Javanese is felt more relevant.

The relevance of translanguaging to deal with the diverse students' profile is also supported by Garcia and Wei. By using students' native languages, teacher can engage all students with the diverse profile. They will become more active while they have to receive the linguistic input from the teacher and further while they are required to produce the adequate linguistic output in meaningful interactions and collaborative dialogue (García \& Wei, 2014). 
Teacher 3 and 4 express the negative feelings towards teacher-directed translanguaging. Teacher 3 says that he feels disappointed.

"What I feel is disappointed. I teach English so I should use English in my class. When in my teaching I use Indonesian or indigenous language that means I don't train them to speak or listen to English."

Meanwhile, Teacher 4 feels sad when she has to use Indonesian in the EFL class.

"It saddens me to use Indonesian instead of English in class. It is an English class and not translated English. When I was in Senior High School, my English teacher used English in his daily teaching and we as students were fine about it."

Both statements indicate that both teachers prefer English as the classroom language to the other students' existing languages. This stance may derive from those teachers' past experience when they were students. Teacher 4 admits that her past EFL teachers used to employ mostly English in English lesson. She assumes that it is a good practice and benefits the students.

However, the idea of isolating the target language (which represents the monolingual ideology) has been long debatable in language teaching especially when it is implemented in the multilingual context (Canagarajah, 2011a). The use of target language-only neglects the nature of how bilinguals think, understand and achieve in the real world context (Cenoz, 2017) because in their dailyness, emergent bilinguals are frequently captured to translanguage in and outside the classroom as many studies have revealed (Alby \& Léglise, 2017; García \& Wei, 2014; Krause \& Prinsloo, 2016; Rasman, 2018; Ting \& Jintang, 2020). Although many teachers still insist on the use of target language only to make sure that students are on the right track in learning target language, as implied by teacher 3 , the study with pre-service teachers find no correlation between teacher L1 use and L1 use by beginner and lower-intermediate learners. Furthermore, there is no significant increase in student target language use when the teacher uses the target language exclusively or almost exclusively (Macaro, 2001). Even the use of target language-only in learning may result in students' mutism and decreasing interaction in the classroom as what happens in India (Silencing by English) (Annamalai, 2018). To avoid this unsupportive classroom environment, translanguaging may come as a pedagogical tool to create a more desirable and interactive classroom.

\section{Cognition}

Despite various emotional responses regarding teacher-directed translanguaging, the classroom observations captured all participants to translanguage in their EFL class. Two EFL teachers in East Nusa Tenggara shuttled between English and Indonesian. Besides, two teachers in Central Java incorporated English, Indonesian, and Javanese in some typical situations during the teaching. When they were asked to clarify about why they employed translanguaging, all participants associated teacherdirected translanguaging with the positive attributes which indicated their positive beliefs as well.

In their comments, every participant tends to relate their translanguaging strategy with the following positive outcomes. Firstly, translanguaging enables students to achieve a better understanding of the teaching materials. Secondly, translanguaging enables students to achieve a better understanding of the given instruction. For example, Teacher 4 says:

"It is more effective to make them understand the material and simple classroom instruction. Sometimes I have to repeat the same instruction in Indonesian to make them understand what to do in my class. Using Indonesian fits my students who are not so good in English".

The teacher mentions clearly that her translanguaging assists her students to digest the material and understand the classroom instruction. Meanwhile, Teacher 3 also says:

"I mean in English class, 80\% of languages must be English. I use Indonesian because if I speak all English, no reaction from students. They wouldn't know what to do in class"

The teacher implies the significance of teacherdirected translanguaging to stimulate students' reaction towards the classroom instructions because talking in the target language-only leads to the students' mutism.

These findings are in line with Wang's who concludes that teachers' translanguaging can serve as explanatory and managerial strategy (Wang, 2016). It means that teacher can translanguage as a strategy to explain the concepts or teaching materials and also to manage their classroom through the instructions that can be well-understand by students. Sometimes, teaching materials and classroom instruction delivered through the target language cannot be absorbed by all students at the early stage of language learning because of the lack of processing for meanings (Baker, 2001). Therefore, teachers can employ other languages like Indonesian and Javanese as the resources to open up students' access towards the essential information, detailed explanation or teacher's clarification during class.

Regardless of the two positive attributes explained previously, Teacher 1 and Teacher 2 also associated teacher-directed translanguaging with two others positive attributes. Firstly, translanguaging 
save the students from learning fatigue. Secondly, translanguaging supports the low English proficiency students. For instance, Teacher 1 says:

"In the middle of teaching, students may be fatigued and became more relaxed when I used languages they know well. They feel like home when I use Indonesian or especially Javanese because that language is the language they speak with their family at home."

The teacher insists that there are some situations in which students may be fatigued when they are constantly subjected to monolingual exposure through the activities of listening, speaking, reading or writing in English. To release them from the learning fatigue, and at the same time keep them on-task, teachers can explain concepts, clarify or ask questions in students home language. It may be an effective way to solve their fatigue because Siegel also reports that students themselves tend to translanguage when they experience L2 fatigue or overload. Their translanguaging activities is captured in their notes during the target language listening activities (Siegel, 2020). Teacher 2 also says:

"Using English only in the EFL classroom doesn't help the low English proficiency students as what I said before that some students in my class just started to learn English in Junior High School. I have to use Indonesian and Javanese"

Teacher 2 highlights teacher-directed translanguaging as a support for the low English proficiency students. Imposing English only in EFL class could mean leaving the low English proficiency students without adequate support for learning because of their limitation as emergent bilinguals to engage in a meaningful classroom interaction. Therefore, teachers need to open more opportunities for all classroom participants to engage in classroom communication. By translanguaging, more students are included with all linguistic repertoire they have. Even the students with low English proficiency are going to be able to learn and become more active in the classroom. A previous study indicates that translanguaging is desirable by most Indonesian EFL teachers because of this reason. The majority of EFL teachers in Indonesia tended to support translanguaging as a beneficial teaching and learning tool because it was assumed to help the lower proficiency students (Khairunnisa \& Lukmana, 2020) in order to obtain the better teaching and learning results.

\section{Conation}

For the intentional behavior, all participants hold a positive stance regarding teacher-directed translanguaging except teacher 4 who has a mixed stance. Teacher 1, Teacher 2 and Teacher 3 agree that in the future they would need to translanguage considering the potential advantages as described in the previous part. For example, Teacher 2 says:

"The institution where I work is not an international school that usually attracts students with good English proficiency. So, I don't think that I would use English only. "

The teacher is not sure that in the future she would have students with good English proficiency. This type of student tends to opt for international schools while her school is not one of them. Therefore, she would rely on translanguaging for her future English teaching.

Meanwhile, Teacher 4 argues that the future decision to translanguage or not would depend on his future students' English proficiency.

"It depends on the students. If I teach low proficiency students, I'll use Indonesian in class since they won't understand a thing if I speak in English."

Teacher 4 would employ a more flexible strategy depending on students' profile and students' needs. If the students still have low English proficiency, home language would be employed. Otherwise, if the students already have high proficiency meaning that they could understand the topics and materials delivered in the target language, she would employ English-only

\section{Teachers' Attitude towards Student-Directed Translanguaging}

The following Table 2 describes teachers' attitude towards student-directed translanguaging.

Table 2

Teachers' Attitude Towards Student-Directed Translanguaging

\begin{tabular}{llll}
\hline & Affect & Cognition & Conation \\
\hline T1 & Mixed & Positive & Positive \\
T2 & Positive & Positive & Positive \\
T3 & Mixed & Positive & Positive \\
T4 & Mixed & Positive & Positive \\
\hline
\end{tabular}

Regarding student-directed translanguaging, most teachers express once again the positive attitude which is reflected through nine positive comments that can be seen in the table. Three other comments are categorized as mixed.

\section{Affect}

No participant feels negative emotions towards student-directed translanguaging. While Teacher 2 expresses the positive feeling, Teacher 1 , Teacher 3 and Teacher 4 indicate the mixed feelings.

Teacher 2 says that she feels happy when students' translanguaging leads them becoming more active and capable of finishing the given task. 
"I mean if they speak up, ask me questions in Indonesian and Javanese, and then get explained and it results in their capability to finish the given tasks correctly, I feel beyond happy."

The teacher highlights the practicality of allowing student-directed translanguaging. For teacher 2, as long as students' use of Indonesian and Javanese increases their participation and performance on the given task, the strategy should be employed. EFL teacher has to be more practical, anything useful to achieve the primary goal should be strategically employed including allowing students to translanguage (Wang, 2016).

The three other teachers show mostly hesitation whether or not to allow students' translanguaging in their EFL class. Teacher 1 and Teacher 4 says that they do not angry or happy at students who use languages other than English. In the learning process, student-directed translanguaging is normal. Meanwhile Teacher 3 says:

"I am disappointed when they use Indonesian mostly. Using too much Indonesian is not good for them and I may fail because the learning goals are unachieved. But when they start to mix the languages or use more English than Indonesian, I'm grateful"

On the one hand, the teacher feels disappointed if students use more Indonesian without any effort to involve the target language. On the other hand, he feels grateful if students mix the languages, use Indonesian and English back and forth, within or between sentences. It is more acceptable.

The teacher implies that student-directed translanguaging may lead to the overuse of language other than English in the EFL class. This caution is also delivered by teachers in Japan (McMillan \& Rivers, 2011). If English is not dominant, the use of other languages can be used excessively and it is assumed to bring detrimental effects on students' target language learning. The teacher is also worries about the curricular goals achievement when Indonesian is overused. Teaching and learning English in the Indonesian EFL context has goals to achieve in line with the national curriculum. There are a series of core competencies and basic competencies students need to achieve by the end of semester. Those competencies seem hard to be elicited by the students when during the process they get used to use more Indonesian.

\section{Cognition}

Although some participants express the feeling of hesitation towards student-directed translanguaging, the classroom observations captured all participants to allow student-directed translanguaging in their EFL class. While students in East Nusa Tenggara switched between English and Indonesian with their typical accent, those in Central Java used English, Indonesian, and Javanese during the lesson. All participants who were asked why they allowed students to translanguage associated student-directed translanguaging with positive attributes as follows.

Teacher 1 relates student-directed translanguaging with the positive outcome as it enables student to perform their knowledge. She says:

"I let my students speak Indonesian or Javanese so that they are able to deliver what they truly mean, what they know."

The teacher believes that student-directed translanguaging help the students to deliver their actual knowledge about a topic or the answer to a given question. Sometimes, students may already know about something but they do not know how to say it in the target language. They wish to participate but at the same time they encounter difficulties to engage if the teacher demands too much English to be used. Thus, allowing students to use their existing languages may solve the problem. It helps them demonstrate what they truly know in co-construction dialog in which their understanding is mediated each other (García \& Wei, 2014).

Teacher 2 and Teacher 3 associate studentdirected translanguaging with creativity. Teacher 2 says:

"We need to appreciate students' effort to speak English even though they insert some Indonesian and Javanese words in their utterances. It is a creative work."

Meanwhile, Teacher 3 also says:

"When they speak English and then mix it with Indonesian, the good point is, it helps them to get out of trouble, they can answer a given question even in broken English but that means they are able to explore themselves."

Both teachers assert on students being creative linguistically. Their efforts to use English by mixing their utterances with some Indonesian and Javanese words must be appreciated. It proves that they maximize all linguistic resources they have for communication purposes. This creativity through translanguaging is also emphasized by Wei. That creativity refers to the ability to choose between following and flouting the rules and norms of behavior, including the use of languages (Wei, 2011). In translanguaging, students have more freedom to select all resources drawn from their linguistic repertoire to deal with their speaking problem.

Teacher 4 relates students' translanguaging with another positive outcome as it facilitates students' discussions. She says:

"I notice my students almost always speak Indonesian within groups or with their friends. 
I allow them to speak Indonesian as long as they discuss the given task or the content material. It may help them to get better understanding between each other."

The teacher admits that her students use Indonesian multiple times especially in studentstudent interaction. It is important for students' learning especially when they discussed the task and content material to elicit better understanding.

This finding is similar to the previous findings revealed by Wang and Rasman. Wang reports that students in Mainland China often interact with each other using multiple languages to translate questions raised by teachers to classmates sitting nearby (Wang, 2016). Rasman also reveals that some students may independently scaffold to solve the given task during a group discussion (Rasman, 2018). It is proven that until the use of languages other than English namely Javanese and Indonesian, the task is unsolved and the students do not realize the mistranslation they have done.

\section{Conation}

Envisaging their future EFL class, all teachers have a positive stance towards students' translanguaging. All teachers open the opportunity for studentdirected translanguaging in their future EFL class as they say that they would encourage students to use students' existing languages in learning. For example, Teacher 4 says:

"It depends on my students' English proficiency level which is impossible that they all would have had excellent English in Grade VII or VIII. I'd prefer they mix the languages, not too much Indonesian".

The teacher still believes that her future students would need Indonesian in the class. She is not sure that her students would already have high English proficiency in Grade VII or VIII. Therefore, she would still provide translanguaging space in her future EFL class. Indonesian would be allowed but the students were not expected to use it frequently.

\section{Translanguaging Practice in Indonesian EFL Classroom \\ Teacher-directed translanguaging}

In general, teacher-directed translanguaging was conducted by all participants as explanatory and managerial strategies. For explanatory strategies, the teacher provided scaffolding for meaning-making activities such as explaining grammar rules and lexical uses, translating new words and elaborating concepts. Meanwhile, the managerial strategies by using translanguaging were reflected in the teachers' ways of providing the operational instruction such as giving commands for classroom activities, giving feedback and assignments, and checking the comprehension of learning content. Only by using students' home languages, students could give the appropriate reaction towards what had been said by the teachers. They could rise questions, answer teachers' questions and interact with the teacher during the EFL class.

The following example illustrates how teacherdirected translanguaging was conducted in an EFL class located in East Nusa Tenggara, especially, to give instruction.

\section{Extract 1}

Teacher 3: Selamat pagi semua

Students : Pagi Pak $<$ Good morning all>.

$<$ Good morning teacher>

Teacher 3: How are you today?

Students : Fine

Teacher 3: Ok, I hope all of you fine.

Semuanya baik <all good>, terlebih di situasi seperti ini ya <especially in this situation>. Ok, this morning we are going to discuss about recount text. Omong tentang text recount yah <Talk about recount text yeah>. Ok, I want to ask you about your activities. Saya mau tanya kau punya kegiatan yang kalian buat pada waktu yang lalu < I am going to ask you about the activities you have done>. $O k$, nanti <soon> I will give you this paper. Saya akan memberikan eh kertas ini $<$ I will give you a piece of paper>. Dan anda akan menulis kegiatan yang pernah engkau lakukan di rumah <And you have to write down your activities you have done at home>. Bisa? <Could you do that?>

After greeting the students and sharing the topic of the lesson, the teacher gave instructions to the students about what they were going to do. The instruction was given in English and then followed by translation in Indonesian. It was repeated several times. The instruction was actually the same but in different languages to make sure that students had a fully understanding of how the class would work. This typical situation also happened in another context and was called instruction reinforcement where the translanguaging strategy was initiated by the teacher. Teachers used L1 to repeat an idea or switched to L1 to present classroom instruction. In this way, the teacher highlighted their instruction and captured students' attention (Fang \& Liu, 2020).

\section{Student-Directed Translanguaging}

Unlike the teacher-directed translanguaging, this type of classroom translanguaging served mostly as interpersonal strategies (Wang, 2016) in studentstudent interaction. The students often interacted by using multiple languages to translate questions raised by teachers to classmates sitting nearby or to finish the given task when they had to work in small groups. The use of their languages helped them to consolidate knowledge and understanding of the material in the lesson. It enabled students who had 
the higher English proficiency to assist the lower one without waiting too long for teachers' further explanations about every learning problem they might encounter.

The next example performs how students in an EFL class located in Central Java discussed content or activities in small groups.

\section{Extract 2}

Student A: Eh, eh Ndah gimana?

<Eh Ndah, how we do this?>

Student B: Menurutku penting enek wae.

$<$ For me, just make it>

Student A: Opo? Piye? <What? How?>

Student B:Indonesia ne, Di mana

$<$ In Indonesian, Where>

Student A: Di mana <Where>

Student A started to write down the question in a book.

Student B: Supaya gampang ya Di mana rumahmu. <To make it easy, where is your house located> Where,

Student A: Where, where,

Student B: Sik<Wait a momemt>, di mana rumahmu $<$ Where is your house located $>$ Where live

Student A: Where, ing kene aku nulis live? $<$ Should I write live here?>

Student B: Live tu tinggal? <Live means tinggal?>

Student A: La ngana wae ta. <Just try it> Where

Student B: You live. Where you live.

Student A:Where are you apa where do you? $<$ Where are you or where do you?>

Student B: Where do you live.

Student A: Kenapa pakai do? <Why do we use do?>

Student B: Eh biasanya gitu. <That is the normal.>

Two students were expected to formulate a question by using one question word which had been written on the whiteboard. Those students intended to throw a question: Where do you live? In order to finish the given task in a very limited time, students spontaneously used Indonesian and Javanese. Their understanding was mediated through their stronger languages. It helped them to determine the question in Indonesian and then cooperatively constructed a correct sentence in target language or English.

\section{CONCLUSION}

Based on the research findings and discussion of the study, it is concluded that the participants of the study have a positive attitude towards translanguaging practice in the EFL class. Their positive attitude is illustrated by their dominant positive evaluative judgments towards both teacherand student-directed translanguaging in term of affect, cognition and conation. Despite they feel various emotions towards the practice, all participants associated both types of classrooms translanguaging with the positive attributes. Moreover, almost all participants also have the positive intention towards translanguaging in their future EFL class. The participants' positive attitude towards translanguaging is obviously reflected in their daily teaching.

In this article, translanguaging practice is captured as the prevalent practice in the participants' EFL class. In the EFL class in East Nusa Tenggara where the teachers express the negative feelings, teacher-directed translanguaging using English and Indonesian takes place. Translanguaging serves as translation tool to reinforce the classroom instructions so that the instructions can be understood better by students. Meanwhile, in the EFL class in Central Java, student-directed translanguaging using English, Indonesian and Javanese is also captured. It is beneficial during students' discussion in order to finish the given task.

The contribution of this study is particulary in revealing teachers' attitude towards translanguaging and how the attitude is reflected in the Indonesian real teaching situation. Amid Indonesian EFL teachers' high receptive stance towards translanguaging (Khairunnisa \& Lukmana, 2020), some teachers are aware that translanguaging practice involving teachers' and students' all linguistic repertoire may be risky as well. When the use of languages other than English are excessive, students may not develop. Subsequently, the pedagogical goals are also unachieved

However, this research is limited to teachers' attitude and its implication in EFL classrooms in the limited area of Indonesia. Thus, future studies must include a bigger scope and more importantly to find out how to translanguage (Rasman, 2018) especially in East Indonesia where thousands of indigenous languages are spoken and this superdiversity may be so challenging in classroom translanguaging.

\section{ACKNOWLEDGEMENT}

The support of Indonesia Endowment Fund for Education, abbreviated as LPDP (Lembaga Pengelola Dana Pendidikan) is gratefully acknowledged, as this work derives from its funding.

\section{REFERENCES}

Alby, S., \& Léglise, I. (2017). Multilingualism and translanguaging as a resource for teaching and learning in French guiana. The Multilingual Edge of Education, 115-137. https://doi.org/10.1057/978-1-137-54856-6_6

Annamalai, E. (2018). Nation-building in a 
globalised world: Language choice and education in India. Decolonisation, Globalisation, 20-37. https://doi.org/10.21832/9781853598265-004

Baker, C. (2001). Foundations of bilingual education and bilingualism (3rd ed.). Multilingual Matters Ltd. https://doi.org/10.1075/lplp.21.3.11fer

Canagarajah, S. (2011a). Codemeshing in academic writing: Identifying teachable strategies of translanguaging. The Modern Language Journal, 95(3), 401-417. https://doi.org/10.1111/j.15404781.2011.01207.x

Canagarajah, S. (2011b). Translanguaging in the classroom: Emerging issues for research and pedagogy. Applied Linguistics Review, 2(2011), 1-28. https://doi.org/10.1515/9783110239331.1

Cenoz, J. (2017). Translanguaging in school contexts: International perspectives. Journal of Language, Identity and Education, 16(4), 193198.

https://doi.org/10.1080/15348458.2017.132781 6

Fang, F., \& Liu, Y. (2020). 'Using all English is not always meaningful': Stakeholders' perspectives on the use of and attitudes towards translanguaging at a Chinese university. Lingua, 247, 102959. https://doi.org/10.1016/j.lingua.2020.102959

Faridatuunnisa, I. (2020). Kebijakan dan pelaksanaan pembelajaran bahasa inggris untuk SD di Indonesia. Seminar Nasional Pendidikan, 1(1) 191-199. https://jurnal.ustjogja.ac.id/index.php/semnas2 020/article/view/7510

García, O., \& Wei, L. (2014). Translanguaging: Language, bilingualism and education. Palgrave Macmillan. https://doi.org/10.1057/9781137385765

Jones, B. (2017). Translanguaging in bilingual schools in Wales. Journal of Language, Identity \& Education, 16(4), 199-215. https://doi.org/10.1080/15348458.2017.132828 2

Khairunnisa, \& Lukmana, I. (2020). Teachers' attitudes towards translanguaging in Indonesian EFL classrooms. Jurnal Penelitian Pendidikan, 20(2), 254-266.

Krause, L. S., \& Prinsloo, M. (2016). Translanguaging in a township primary school: Policy and practice. Southern African Linguistics and Applied Language Studies, 34(4), 347-357. https://doi.org/10.2989/16073614.2016.126103 9

Lewis, G., Jones, B., \& Baker, C. (2012). Translanguaging: Developing its conceptualisation and contextualisation.
Educational Research and Evaluation, 18(7), 655-670. http://doi.org/10.1080/13803611.2012.718490

Macaro, E. (2001). Analysing student teachers' codeswitching in foreign language classrooms: Theories and decision making. The Modern Language Journal, 85(4), 531-548. https://doi.org/10.1111/0026-7902.00124

McMillan, B. A., \& Rivers, D. J. (2011). The practice of policy: Teacher attitudes toward "English only." System, 39(2), 251-263. https://doi.org/10.1016/j.system.2011.04.011

Miles, M. B., Huberman, A. M., \& Saldaña, J. (2014). Qualitative data analysis: A methods sourcebook (3rd ed.). Sage Publications. Inc.

Nambisan, K. A. (2014). Teachers' attitudes towards and uses of translanguaging in English language classrooms in Iowa [Unpublished master's thesis]. Iowa State University. https://search.proquest.com/docview/16598197 13 ?accountid= 13375

Rasman. (2018). To translanguage or not to translanguage? The multilingual practice in an indonesian EFL classroom. Indonesian Journal of Applied Linguistics, 7(3), 687-694. https://doi.org/10.17509/ijal.v7i3.9819

Siegel, J. (2020). Appreciating translanguaging in student notes. ELT Journal, 74(1), 86-88. https://doi.org/10.1093/elt/ccz052

Ting, S.-H., \& Jintang, L. (2020). Teacher and students' translanguaging practices in a Malaysian preschool. International Journal of Early Years Education, O(0), 1-15. https://doi.org/10.1080/09669760.2020.185042 9

Wang, D. (2016). Translanguaging in Chinese foreign language classrooms: Students and teachers' attitudes and practices. International Journal of Bilingual Education and Bilingualism, 22(2), 138-149. https://doi.org/10.1080/13670050.2016.123177 3

Wang, D. (2019). Researching classroom translanguaging. In D. Wang (Ed.), Multilingualism and translanguaging in Chinese language classrooms (pp. 97-106) https://doi.org/10.1007/978-3-030-02529-8

Wei, L. (2011). Moment Analysis and translanguaging space: Discursive construction of identities by multilingual Chinese youth in Britain. Journal of Pragmatics, 43(5), 12221235. https://doi.org/10.1016/j.pragma.2010.07.035

Wei, L., \& García, O. (2017). Research methods in language and education. K. A. King, Y. Lai \& S. May (Eds.), Research methods in language and education, 227-240. https://doi.org/10.1007/978-3-319-02249-9

Yin, R. K. (2018). Case study research and 
applications: Design and methods (6th ed.). Sage Publications Ltd. https://doi.org/10.1177/109634809702100108 Yuvayapan, F. (2019). Translanguaging in EFL classrooms : Teachers' perceptions and practices. Journal of Language and Linguistic Studies, 15(2), 678-694.

Zein, M. S. (2017). Elementary English education in Indonesia: Policy developments, current practices, and future prospects. English Today,
33(1), 53-59.

https://doi.org/10.1017/S0266078416000407

Zuniga, C. E., Henderson, K. I., \& Palmer, D. K.

(2017). Language policy toward equity: How bilingual teachers use policy mandates to their own ends. Language and Education, 32(1). https://doi.org/10.1080/09500782.2017.134979 2 